\title{
Union renewal in historical perspective
}

\author{
Richard Croucher \\ Middlesex University \\ and \\ Geoffrey Wood \\ University of Essex
}

\begin{abstract}
This article revisits contemporary union renewal/revival debates through comparison with the late 1930s resurgence of trade unionism in the UK's engineering industry. It is argued that the 1930s union renewal arose from more favourable contextual conditions than those currently obtaining. It was led by political activists, with better-articulated organisation and greater resonance in the working class than their contemporary counterparts, and who were assisted by state policy and pro-worker forces. Conclusions are drawn in relation to current debates.
\end{abstract}

Keywords: union renewal; history; economic crisis; market mediation; United Kingdom Corresponding Author: Richard Croucher, Middlesex University Business School, Hendon, London NW4 4BT, UK (r.croucher@mdx.ac.uk) 


\section{Introduction}

British labour historiography's rich patrimony often reflects sociological concerns, while from the Webbs onwards industrial sociologists integrated historical perspectives into their analyses of contemporary trade unionism (Allen et al, 2010). This article seeks to contribute in these traditions by analysing British trade unionism's 1930s renewal, to provide new perspectives on contemporary union renewal/revival debates. It outlines the major contextual differences between the 1930s and today, showing how activists exploited opportunities and wider pro-labour forces contributed.

The resilient problems currently facing trade unionism internationally have stimulated rich debate on union renewal/revitalisation. Certain themes emerge, including different organising approaches' effectiveness; 'partnership's role; the parts played by political and economistic appeals, the possibilities of wider alliances and 'social movement' unionism (Voss, 2010). However, unions' problems have been especially acute in liberal market economies (Author B and Wright, 2016), generating specific debates. One side in the exchange is pessimistic about British unions' recent history and prospects. It emphasises profound contextual challenges and the pervasive negative effects of neo-liberalism on unions themselves. Gary Daniels, John McIlroy (2009) and others showed how the right decisively shifted the terms of political exchange to unions' detriment, facilitating an historical caesura in workplace relations via a powerful ideological offensive. McIlroy suggests that the post-war settlement survived until the late 1970s; in 1979 'key sections of British capital accepted trade unionism' (McIlroy, 2009a: 35). The Thatcher governments' (1979-1990) attacks on unions stimulated employers to follow suit in companies, decentralising and weakening collective bargaining while degrading fundamental aspects of employment relationships. The consequences were profound. The Twentieth Century's last years represented for unions 'at least in some ways the end of history' (McIlroy, 2009a:12). Re-regulation, de-industrialisation, privatisation and extensions to labour's commodification were accompanied by major declines in union density, morale and members' aspirations. Unions' relations with their 'political wing' deteriorated as the Labour Party adopted a variant of neo-liberalism (McIlroy, 2009b). Unions benefitted little under 'New Labour' governments (1997-2010): although unemployment fell, 'labour market flexibility' and deindustrialisation advanced (McIlroy, 2009b: 72-8). In a range of important unions, disillusionment ensued and internal factional battles brought an 'awkward squad' of leaders to office which articulated discontent with New Labour policies and their consequences, most 
vociferously from 2000-2005 (McIlroy and Daniels 2009: 149-50). Nevertheless, most union leaders felt constrained by their support for Labour, and even the 'awkward squad' was reluctant to embarrass the New Labour Governments through strikes, which remained at an historically low level (Lyddon, 2009: 322). Unions sought to rebuild membership through top-down initiatives, assisting relative stabilisation (Daniels, 2009: 274-7). The central initiative of this type, the Trade Union Congress' s Organising Academy, trained organisers. It was judged a necessary, partially successful but insufficient venture requiring further development; Daniels (2009: 274-6) advocated greater individual union involvement and initiative. Meanwhile, trade union education became increasingly dominated by state-funded 'UnionLearn' programmes designed to encourage 'partnership' and to facilitate individual upward mobility rather than organising capacity or collective bargaining (McIlroy and Author A, 2013).

Others, including Ralph Darlington and Heather Connolly, took more sanguine views. Connolly and Darlington (2012: 248) criticised Daniels and McIlroy's overall verdicts and the 'pessimism' of Melanie Simms and Andy Charlwood (2010), citing instances of 'continuing resilience and combativity in certain areas' (2012: 236). Darlington (2009 a; 2009b) argued that specific historical periods, including the current one, create opportunities for political activists to mobilise workers while invigorating unions. Darlington had already pointed to examples in areas such as Royal Mail (Darlington, 2002) and railways (Darlington, 2009a). Unlike McIlroy and his associates, Darlington and colleagues were not concerned with how activists were developed, outside of political parties and unions; nor were alliances with other organisations stressed. Rather, Darlington emphasised union leaderships' complementary role. While Darlington (2002) previously saw potential in the 'awkward squad' General Secretaries, recently Connolly and Darlington (2012) examined leadership acting in concert with activists in the Rail, Maritime and Transport Union and the French SUD-Rail, using these cases to exemplify their 'radical political trade unionism' construct. They argued that such unions brought results for members and constituted a model of wider significance for the labour movement (2012: 248). McIlroy and Daniels (2009: 157) by contrast had viewed the British union left's overall impact as 'slight'; rather, social movements and 'fringe parties' had 'made the running' in challenging neoliberalism (McIlroy, 2009a: 15).

Some agreement exists between the two schools: both reject 'partnership', and advocate combinations of leadership and activist initiative. Neither emphasises wider alliances. 
Differences exist in the weight they give to broader contexts, in their assessments of political activists' influence, and in their views on how such activists emerge, develop and network. We examine this debate through the lens of a comparison with trade unionism's revival in the engineering industry in the late 1930s. Broadly speaking, it is argued that the 1930s context was more positive than that currently obtaining. We show the upsurge from below that drove revival, activists' and leaders' roles within it and its organisational results. Self-activity was facilitated and channelled by militants characterised as 'political outsiders' by union leaderships anxious to control them. These activists cooperated despite political differences, and were well-prepared. They operated within a broadly-based social movement that transcended unionism while opening possibilities for unions. Membership increases ensued and, eventually, significant changes occurred in the industry's key union's elected leadership and its democratic structures.

\section{Trade unionism's late 1930s revival}

From 1935, state policy was conducive to union development (Howell, 2005:12). While seeking to appease Nazi Germany, the Conservative government sought union cooperation. This was part of a recently-initiated longer-term trend to integrating labour (Howell, 2005:12), which at that point also helped balance the state's increasing reliance on large arms companies with potentially problematic international links. Significant pro-worker legislation--the Factories Act 1937 and Holidays with Pay Act 1938--was enacted (Author A, 1982: 18). Major state investments were made in Britain's arms industries, increasing the demand for labour. Many sizeable new 'shadow' aircraft factories were built, publicly funded but placed under engineering companies' management (Little and Grieco, 2011). The economic and policy environments were not yet as helpful as post-1940 when labour enjoyed exceptional advantages, but were an improvement on the preceding period.

Britain's engineering employers were organised in the Engineering Employers' Federation (EEF). A powerful sub-group, the aircraft employers, was also involved in 'The Ring' (the Society of British Aircraft Constructors: SBAC), created to access, negotiate and distribute government contracts. This group rapidly generated large profits from generous 'cost-plus' contracts; their share prices steadily increased (Author A, 1982: 4). The assumption might therefore be that SBAC companies were anti-Nazi from material interest, but this was not the case. Indeed, the industry's trade newspaper, The Aeroplane, supported 
by the employers, publicised its pro-Nazi sympathies (Author A, 1982: 2-6 and passim). Its editor wrote: 'the main reason I am pro-Nazi is that I admire so intensely the team spirit, and the spirit of patriotism which pervades everything in Germany......we shall arrive at the same sort of thing in our own way' (The Aeroplane, 19 January, 1938). SBAC condoned such statements, confirming the Communist Party of Great Britain's (CPGB) newspaper Daily Worker's arguments about its sympathies, assertions which became increasingly persuasive as war approached. By 1937, elected worker representatives--shop stewards--were threatening strikes if aircraft were sent to Franco's Spanish Nationalists. Days later, the government adopted 'non-intervention' in the Spanish Civil War (Author A, 1982: 44). Thus, soon after the Great Depression, the aircraft employers faced workplace union power with a political dimension; how had it developed?

The EEF and SBAC confronted the Amalgamated Engineering Union (AEU) - a union with a strong craft-democratic identity which dominated worker representation in engineering and claimed primacy within it-- and the much smaller general unions, the Transport and General Workers' Union (TGWU) and the National Union of General and Municipal Workers (NUGMW). The EEF emphatically rejected 'partnership' with unions, as earlier mooted in the 'Mond-Turner' and associated talks. Tripartite meetings had occurred between 1929 and 1931 but, among the employers, the EEF was particularly strongly opposed, citing managerial prerogative concerns (Gospel, 1979: 189-90). Thus, 'partnership' was not available even if unions had desired it. Union officials felt unable to challenge EEF policy of restricting strikes by tying union national executives into a slow, cumbersome national procedure 'for avoiding disputes' which forbade industrial action until it was exhausted (Wigham, 1973). The national unions' commitment to this 'constitutional' modus operandi reflected their fear of devastating retaliatory lockouts such as that of 1922 but also distanced the national officials from the workshops and districts, affording activists a potent argument for industrial action.

As the economy revived, the psychological legacy of earlier defeats and mass unemployment was rapidly overcome and AEU activists spread unionisation. They became heavily involved in a substantial strike wave in which two mobilisations were especially significant. The first was the 1935 Hawker Aircraft strike, in which men and women in two factories struck for a non-unionist's removal and against an unfavourable wage payment system. They successfully requested support from other aircraft factories, defying the AEU's instructions to return to work and to use the national procedure. The TGWU capitalised by recruiting many 
women. Ultimately, the non-unionist left his employment and the dispute ended in compromise, but the links formed by the Hawker stewards constituted the foundations of a national aircraft shop stewards' network. The network-the Aircraft Shop Stewards' National Council (ASSNC)--published a national newspaper, New Propellor, achieving considerable worker involvement in its columns and a wide circulation in the workshops while pursuing a combative dialogue with The Aeroplane. By 1938, over 50 factories took 20,000 copies, equivalent to one in six aircraft workers (Author A, 1982: 41). From 1935 onwards, the ASSNC and New Propellor led a groundswell of shop floor activity which dramatically improved unionisation, bringing membership in many aircraft factories above 90 percent. In 1940, the ASSNC expanded to cover the whole engineering industry; its conference that year attracted 283 shop steward delegates from over 100 factories (Author A, 1982: 41, 113). When war arrived and the Daily Worker was banned for opposing the war, New Propellor was exempted from similar treatment by the War Cabinet on Ernie Bevin's (the influential Minister of Labour) advice that suppressing it might create industrial problems (Author A, 1982:115). As illustrated below, Bevin was not thereby demonstrating any sympathy with Communism.

The second major mobilisation, the 1937 apprentices' strike, was an industrial generational revolt involving hundreds of thousands of workers, very much led from below by the apprentices' committees, sometimes involving the Young Communist League. The committees channelled high levels of collective self-activity by apprentices, supported by adult workers and industrial communities (Ryan 2004). The contrast with recent years, when younger workers have been only weakly involved in collective organisation, is marked. The apprentices sought wage increases and union recognition, creating a rolling strike wave which swept southwards from Scotland across Britain. New Propellor justifiably announced in a headline 'YOUTH MAKE HISTORY' (Author A, 1982: 45-53). Women workers such as the 8,000 at Courtaulds large Coventry rayon factory, among others, struck in support (Author A, 1982: 55). By late 1937 the apprentices had secured wage increases and the AEU had won the right to negotiate for them, something it had long unsuccessfully sought through national discussions with the employers (Author A, 1982: 56-7). These massive strikes generated inter-generational appeals for support ('Don't work today daddy!' was one of the apprentices' calls) and pushed adult trade unionists to review their own attitudes and activity.

In comparison with their contemporary counterparts, the 1930s industrial political activists were relatively well-placed to lead and organise widespread solidarity with the strikes. The 
working class leftists who played such a major role in re-building the unions were organically linked to those whom they organised, and were firmly anchored in working class communities which had not yet been dispersed as they were later to be (Cronin, 1984). Many were not Communists, but the numerous Communists among them could access substantial international and national support structures. The leading political engineering militants were skilled workers and employers desperately needed their skills. Communists' political allegiances were far from being entirely positive: responding to USSR-dominated Comintern policy, they performed constant industrial-political twists and turns ${ }^{i}$. Shop floor Communists did not always accept, foreground or emphasise party lines, but during the 'Popular Front' (1935-1939), when Communists internationally built a broad popular movement to combat fascism, it was easier for them to follow the party line than it had been in the early 1930s when they had attacked social democrats. From 1935, the CPGB increasingly advocated alliances within and beyond the labour movement. Allegiance to the USSR was less markedly problematic than later in 1939 when the Hitler-Stalin pact pushed Communists internationally to oppose the war, until the USSR was invaded in 1941 and the policy was reversed.

Although influential, Communists were only one grouping within a broader set of leftists active in the factories. Most had clear if varied answers to the question 'organising for what?' posed by Melanie Simms and Jane Holgate (2010): ultimately, it was to propagate alternative visions of society. Thus, in 1937, The Aeroplane suggested that De Havilland's Edgware works contained a 'cell' of nine Communists operating together with ten other leftists from the Independent Labour Party (ILP), Industrial Workers of the World (IWW), Labour Party and Socialist League (Author A, 1982: 35). The first three organisations were strongly oriented towards stimulating industrial workers' collective action. The leftist industrial political landscape was nonetheless more diverse than that observed decades later by Darlington (2009a) and Martinez-Lucio and Stuart (2009). Whilst sectarian intra-left disputes raged after Germany invaded the USSR in 1941, left workplace activists operated relatively collectively in the 1930s (Author A 1982: 35).

Socialist feminists also made key contributions, engineering a major political breakthrough on which industrial activists capitalised. The relationship between the two groups was symbiotic despite very different backgrounds and approaches. Feminists were central to the long-running inter-war political campaign leading to the 1938 Holidays with Pay Act which recommended but did not mandate paid holidays. Their agitation was 
supported by innovative political appeals which built public recognition of (in their words) the 'poor suffering British housewife's position. Their arguments gradually legitimated the union demand for paid leisure time. The campaign, prior to the Act but especially after its passage created space for unions to agitate and to conclude a growing number of paid holiday agreements with employers (Dawson 2007: 279; Author A, 1982: 32). Many British families enjoyed paid holidays for the first time, a massive historic achievement (Dawson, 2007).

Many of the industrial activists involved in negotiating such agreements had benefitted from the workers' education movement. Vivien Schmidt's (2008) conceptualisation of 'discursive institutionalism' as the 'iterative process of conveying ideas' elucidates how activists' attributes may facilitate institutional and industrial change. Schmidt (2008) highlighted two essential elements: discourses between actors, and between actors and wider society. To create change, actors require ‘background ideational abilities' which develop effective political ideas, and 'foreground discursive abilities' to communicate them. Many 1930s activists displayed both in their practice; they had frequently developed their background ideational capacities through workers' education in its diverse independent interwar institutions as well as elsewhere (Author A, 1982). The workers' educational bodies included workers' clubs, the Labour Colleges and The Plebs magazine—a fierce defender of the need to keep workers' education independent. The Plebs supported many autodidacts as well as study group participants. Tens of thousands were involved (Rée, 1984). Further, many activists took opportunities to develop their foreground discursive skills through the CPGB-led National Unemployed Workers' Movement (NUWM) (Author A, 1987; this paragraph draws on this work). The NUWM existed as a national organisation between 1920 and 1940, providing organising opportunities for the unemployed when trade unionism offered reduced possibilities. The Trades Union Congress, after a brief period in the early 1920s, refused its cooperation. Nevertheless, the NUWM became a mass organisation. It organised national and regional marches, supported strikes, campaigned for unemployed union members to retain union democratic rights, and for unions to adopt pro-unemployed policies, propagating radically different politics from those of the supplicant Jarrow 'Crusade'. Many of its activists of both genders became active union members and shop stewards in and after the rearmament period (Author A, 1982; Author A, 1987). Thus, while rearmament increased the number of industrial jobs, broadening the organising domain, the existence of an experienced group of activists meant that the opportunities presented could be readily seized. 
Activism brought democratic changes in unions, but official union reactions were initially negative and positive institutional modifications took time. National union leaderships disliked challenges to their authority, valued procedural arrangements with the employers and opposed 'extremist' political orientations. They warned and disciplined those who had led 'unconstitutional' strikes. They never recognised the aircraft shop stewards' organisation, nor the apprentices strike committees; the AEU instructed apprentice strikers to return to work (Ryan, 2004: 24-5). The AEU leaders were particularly opposed to crossdistrict shop stewards' organisations, seen as dangerously independent of existing district and national structures (Author A, 1982:37). Similar fears existed in the TGWU's leadership. Ernie Bevin, TGWU General Secretary in the 1930s, isolated the London bus workers' rank and file movement and ended their 'Coronation Strike' (1937) while disciplining its Communist leaders, effectively ending the movement and sending a clear message to their counterparts in other industries (Branson and Heinemann, 1973: 143 and passim). Thus, the AEU and TGWU sought to subordinate 'outside' militants - as union leaders characterised them for rejecting the customary separation of the industrial and political practised in the British labour movement (Minkin, 1991). Many activists nevertheless continued to organise workers and to build the ASSNC while_encouraged by the CPGB-- arguing for leadership and democratising change within unions. Consequently, the key engineering union's leadership moved left, with the prominent ex-syndicalist Jack Tanner's 1939 election as AEU National President; by 1940 the government noted that key AEU district committees were under Communist influence. The union's structures provided increased opportunities for women and young workers' participation in the next decade (Author A, 1982: 65, 113 and passim).

\section{Discussion and Conclusion}

This section crystallises the relevance of the 1930s experience to the contemporary debate outlined above. One of the shared stances taken by the two sides is a rejection of 'partnership'. The 1930s experience supports that view, as 'partnership' played no role in extending unionisation. In the 1930s, the AEU's identity remained strongly independent as a union with stubbornly craft traditions, lacking the appetite and opportunity to participate in 'partnerships'. Three more contentious areas are now examined in turn: how history informs our judgements on disagreements about current contexts, political militants' role and significance, and how the latter are developed and networked. Finally, the current relevance 
of the significant ways that pro-worker extra-union forces assisted the 1930s revival is highlighted.

The late 1930s clearly presented radically different economic, political and social contexts from those of the early $21^{\text {st }}$ Century as extensively detailed by McIlroy and colleagues, which can only be briefly sketched here. All of our arguments must be viewed in the light of these marked contextual differences. In sharp contrast to today, organised labour's role was legitimised by the state as a counterweight to employer power. McIlroy and collaborators emphasise neo-liberalism's pervasive effects on unions through hostility to state expenditure, marketisation, de-industrialisation, corporatisation, anti-labour legislation and encouragement of managerial offensives against labour. They also show how the dramatic decline of traditional manufacturing employment with large-scale fixed workplaces, soon replaced by contingent and gig working in an expanded service sector drastically reduced the base for conventional union mobilisation. Change since they wrote has deepened the contrast between the 1930s and the present. The legal context has further deteriorated, reducing worker rights and underpinning increased precariousness of employment and earnings (Smith, 2015). Employer delinquency as manifested in, for example, unlawfully unpaid wages, is apparently increasing (Citizens' Advice Bureau 2016:2). More broadly, capitalism is not generating sustained upswings such as that initiated by the state in the late 1930s, but rather spurts of volatile and speculation-driven growth which inevitably burst, bringing inappropriate demands for more 'flexible' labour markets.

Darlington and colleagues stress political militants' current significance, and also argue that leaders have recently assisted them in building 'radical political trade unionism.' McIlroy and colleagues take a relatively pessimistic view of the left currently, assigning narrower significance than Darlington to its activities in unions from the 1990s onwards. Their arguments cast particular doubt on 'radical political trade unionism's wider resonance beyond those immediately involved, in the current climate. The historical contrast is of interest here. In the 1930s, political activists were assisted by the rearmament upturn and by their coordination but above all by the upsurge from below, not by union leaderships. The upsurge was initially stimulated by a diverse body of activists but it subsequently carried them forward. They drew confidence from the workshop movement, driving union revitalisation despite being disciplined by unions. The current lack of anything approaching an equivalent 
groundswell hampers activists' organising possibilities and, even if national procedural agreements no longer constrain them as they did in the 1930s, discourages most union leaders from empowering political activists as Darlington (2009) recommends.

Few authorial claims of wider resonance among other workers are made for the strikes led by the activists Darlington and Connolly focused on since 2002: those in Royal Mail (Darlington, 2002) and the rail industry (Darlington, 2009a). In 1937, by contrast, activists' resonance was both wide and intense. Working class communities were pulled into solidarity with the apprentices, and the revitalising effects of the apprentices' action on workplace organisation more widely were strong (Author A, 1982: 45-57). As shown above, women workers outside engineering struck in support, while national organisations coordinated activists, sought solidarity and articulated workers' case to wider audiences. It can be argued that, despite many current publications, no equivalent to the ASSNC nor the New Propellor currently exists, that enjoy the same degree of worker participation and public influence in both engaging with workers and pursuing public political debate with employers. Thus, although Darlington and colleagues' arguments are at one level supported by history, at a deeper level they are qualified by it.

How activists develop themselves and network is the third area of debate, and helps illustrate this argument. McIlroy and Author A (2009) show how workers' education has, in recent years, decreasingly provided opportunities for the development of Schmidtian capacities (Schmidt, 2008); Darlington refers solely to left political parties which, as programmatically-oriented organisations provide more opportunities for 'foreground' than 'background' development. Peter Fairbrother (2005) explained how independent workers' education, conducted outside political parties, can assist union renewal by developing activists' background capacities, while providing networking opportunities. His argument was not widely discussed, but requires more attention since history supports it. As noted above, a key feature of the 1930s educational institutions was their independence as well as their reach; contemporary activists need equivalent sites where their background ideational capacities may be developed and, crucially, where collective interests may also be freely defined by participants, and appropriate action planned. There is, in short, a need to revive independent workers' education. Clearly, campaigning can also develop activists' foreground discursive capacities as an integral part of advancing important causes. Here again, the current opportunities provided by the small, local, lobbying and self-help organisations of the unemployed are very limited in comparison to those offered by the 
NUWM. Finally, non-union, pro-worker organisations supported union revival in other significant ways. The NUWM negotiated a national employment welfare system with the state, underpinning workers' labour market position. Other forces also played a part. 1930s feminists developed a pro-worker consensus and legislative breakthrough, providing industrial activists with important bargaining opportunities. Neither side in the contemporary exchange emphasises analogous possibilities, but feminists' earlier role hints at their potential importance today. Contemporary feminism, it has been powerfully argued, is re-visiting its broad emancipatory traditions and renewing its earlier concern with labour and employment issues (Fraser, 2012). Feminism contains some elements which are focusing on the resilient problems of distributional equity at work (Fraser, 2012).

However, the recent seismic political developments in the USA and UK manifested in Trump's election and Brexit dwarf such shifts, and pose serious issues for unions. A central difference between the crisis of the early twentieth century and its contemporary counterpart is that the former was most intensely felt in the coordinated economies of continental Europe. It completely discredited conventional politics and economic policies, creating opportunities for devastatingly effective far right populist demagoguery. Although the latter did seep into political discourse in the US and the UK, economic and political conditions were insufficiently adverse as to stimulate similar developments there. In contrast, although contemporary right populism exerts influence in many different countries, its most spectacular advances have been in the UK and USA, where they have defined national political discourses. Traditional working class political identifications are clearly in flux, while right populism currently contains major anti-organised labour components. These developments further underline the current contextual difficulties faced by unions (Author B and Wright, 2016).

Failing a substantial upswing enhancing workers' bargaining position and opening opportunities for mobilization, the 'immense efforts' called for by McIlroy and Daniels (2009:12) will indeed be required from unions whose resources — a subject attracting little attention in this debate - as well as confidence have been severely depleted. The late 1930s experience shows the possibilities of wider alliances and suggests how political activists might potentially impact events if they were sufficiently supported by pro-labour forces. Construction of a wider pro-worker political ecology therefore appears important if contemporary union revival is to be achieved. 


\footnotetext{
${ }^{\mathrm{i}}$ The Comintern-The $3^{\text {rd }}$ (Communist) International-existed from 1919 as the coordinating body for Communists worldwide until Stalin dissolved it in 1943. From soon after its foundation it became increasingly an instrument of Soviet foreign policy.
}

\section{Acknowledgement}

The authors would like to thank Jimmy Donaghey, and WES's anonymous reviewers for commenting on earlier drafts of this article.

\section{References}

Allen J Campbell A McIlroy J (2010) Histories of Labour: National and Trans-national Perspectives. London: Merlin Press.

Author A (1982)

Author A (1987)

Author B Wright M (2016) What Brexit Tells us About Institutions and Social Action. SocioEconomic Review (in press).

Branson N Heinemann M (1973) Britain in the 1930s. London: Panther.

Connolly H Darlington R (2012) Radical political unionism in France and Britain: a comparative study of SUD-Rail and the RMT European Journal of Industrial Relations 18 (3): 235-250.

Citizens Advice Bureau (2016) Advice Trends Q3 October-December 2015-15. London: CAB.

Cronin J (1984) Labour and Society in Britain 1918-1974. London: Batsford Academic. Daniels G (2009) In the field: A decade of organising. Daniels G McIlroy J (eds), Trade Unions in a Neoliberal World. London: Routledge, 254-282.

Darlington R (2002) Shop floor leadership, left-wing activism and collective workplace organisation. Capital and Class 26 (1): 95-126.

Darlington R (2009a) Leadership and union militancy: The case of the RMT. Capital \& Class 33(3): 3-32.

Darlington R (2009b) Syndicalism and the transition to communism: An international comparative analysis. London: Ashgate Publishing.

Dawson S (2007) Working class consumers and the campaign for holidays with pay.

Twentieth Century British History 18(3): 277-305.

Fairbrother P (2005) Rediscovering union democracy: Processes of union revitalisation and renewal. Labor History 46(3): 368-377.

Fraser N (2012) Le féminisme en mouvements:de l'insurrection des années 60 au néoliberalisme. Paris: La Découverte.

Gospel H (1979) Employers' labour policy: a study of the Mond-Turner talks 1927-33.

Business History 21 (2): 180-197.

Howell C (2005) Trade unions and the state: The construction of trade union institutions in Britain, 1890-2000. Princeton: Princeton University Press.

Little S E Grieco M (2011) Shadow factories, shallow skills? An analysis of work organisation in the aircraft industry in the Second World War. Labor History 52 (2): 193-216. Lyddon D (2009) Strikes. Industrial conflict under New Labour. Trade Unions in a NeoLiberal World Daniels G McIlroy J (eds.):316-341. 
Martinez-Lucio M and Stuart M (2009) Organising and union modernisation: Narratives of renewal in Britain. Gall G (ed) Union Revitalisation in Advanced Economies London:

Palgrave: 17-37.

McIlroy J (2009a) Introduction: trade unions in a neo-liberal world. Trade Unions in a Neo-

Liberal World Daniels G McIlroy J (eds.): 1-18.

McIlroy J (2009b) A brief history of trade unions under New Labour. Trade Unions in a NeoLiberal World Daniels G McIlroy J (eds.): 21-62.

McIlroy J Daniels G (2009) An anatomy of British trade unionism since 1997. Organisation, structure and factionalism. Trade Unions in a Neo-Liberal World Daniels G McIlroy J (eds.): 127-164.

McIlroy J Author A (2013) British trade unions and the academics: the case of

Unionlearn. Capital and Class 37 (2): 263-284

Minkin L (1991) The contentious alliance. Trade unions and the Labour Party. Edinburgh:

Edinburgh University Press.

Rée J (1984) Proletarian Philosophers: problems in socialist culture in Britain 1900-1940.

Oxford: OUP.

Ryan P (2004) Apprentice strikes in the Twentieth Century UK shipbuilding and engineering industries. Historical Studies in Industrial Relations 18: 1-63.

Schmidt VA (2008) Discursive institutionalism: The explanatory power of ideas and discourse. Annual Review of Political Science 11(1): 303-326.

Simms M Holgate J (2010) Organising for what? Where is the debate on the politics of organising? Work, Employment and Society 24(1): 157-168.

Simms M Charlwood A (2010) Trade unions: power and influence in a changed context.

Colling T Terry M (eds) Industrial Relations: Theory and Practice. Oxford: Wiley-Blackwell: 125-148.

Smith P (2015) Labour under the law: a new law of combination, and master and servant, in $21^{\text {st }}$ Century Britain? Industrial Relations Journal 46 (5-6): 345-364.

Voss K (2010) Democratic dilemmas: union democracy and union renewal. Transfer:

European Review of Labour and Research 16(3): 369-382.

Wigham E (1973) The power to manage. A history of the Engineering Employers'

Federation. London: Macmillan.

\section{Author Biographies}

\section{Richard Croucher}

Geoffrey Wood 
Professor Geoffrey Wood is Dean and Professor of International Business, at Essex Business School. Previously he was Professor of International Business at Warwick Business School, UK. He has authored/co-authored/edited sixteen books, and over one hundred and fifty articles in peer-reviewed journals. Previously he was Professor of International Business at Warwick Business School, UK. He holds honorary positions at Griffith and Monash University in Australia, and Witwatersrand and Nelson Mandela Universities in South Africa. Geoff's research interests centre on the relationship between institutional setting, corporate governance, firm finance, and firm level work and employment relations. 